\title{
Impact of Fatty Acid-Binding Proteins in $\alpha$-Synuclein-Induced Mitochondrial Injury in Synucleinopathy
}

\author{
An Cheng ${ }^{1}{ }^{\oplus}$, Wenbin Jia ${ }^{1}\left(\right.$, Ichiro Kawahata ${ }^{1,2}{ }^{\circledR}$ and Kohji Fukunaga ${ }^{1,2, *}$ \\ 1 Departments of Pharmacology, Graduate School of Pharmaceutical Science, Tohoku University, \\ Sendai 980-8578, Japan; cheng.an.q6@dc.tohoku.ac.jp (A.C.); jia.wenbin.t6@dc.tohoku.ac.jp (W.J.); \\ kawahata@tohoku.ac.jp (I.K.) \\ 2 Department of CNS Drug Innovation, Graduate School of Pharmaceutical Science, Tohoku University, \\ Sendai 980-8578, Japan \\ * Correspondence: kfukunaga@tohoku.ac.jp; Tel.: +81-(22)-795-6837
}

Citation: Cheng, A.; Jia, W.;

Kawahata, I.; Fukunaga, K. Impact of Fatty Acid-Binding Proteins in $\alpha$-Synuclein-Induced Mitochondrial Injury in Synucleinopathy. Biomedicines 2021, 9, 560. https:// doi.org/10.3390/biomedicines9050560

Academic Editor: Shaker A. Mousa

Received: 17 April 2021

Accepted: 14 May 2021

Published: 17 May 2021

Publisher's Note: MDPI stays neutral with regard to jurisdictional claims in published maps and institutional affiliations.

Copyright: (c) 2021 by the authors. Licensee MDPI, Basel, Switzerland This article is an open access article distributed under the terms and conditions of the Creative Commons Attribution (CC BY) license (https:// creativecommons.org/licenses/by/ $4.0 /)$.

\begin{abstract}
Synucleinopathies are diverse diseases with motor and cognitive dysfunction due to progressive neuronal loss or demyelination, due to oligodendrocyte loss in the brain. While the etiology of neurodegenerative disorders (NDDs) is likely multifactorial, mitochondrial injury is one of the most vital factors in neuronal loss and oligodendrocyte dysfunction, especially in Parkinson's disease, dementia with Lewy body, multiple system atrophy, and Krabbe disease. In recent years, the abnormal accumulation of highly neurotoxic $\alpha$-synuclein in the mitochondrial membrane, which leads to mitochondrial dysfunction, was well studied. Furthermore, fatty acid-binding proteins (FABPs), which are members of a superfamily and are essential in fatty acid trafficking, were reported to trigger $\alpha$-synuclein oligomerization in neurons and glial cells and to target the mitochondrial outer membrane, thereby causing mitochondrial loss. Here, we provide an updated overview of recent findings on FABP and $\alpha$-synuclein interactions and mitochondrial injury in NDDs.
\end{abstract}

Keywords: $\alpha$-synuclein; fatty acid-binding proteins; neurodegenerative disorders; mitochondria

\section{Introduction}

Neurodegenerative disorders (NDDs) are characterized by the progressive deterioration of neurons, followed by degeneration of the structure and function of axons, dendrites, and synapses, and finally leading to neuronal death [1] or dysfunction of myelination [2]. Several diseases are under the umbrella of NDDs, most of which are Alzheimer's disease (AD) and Parkinson's disease (PD), caused by neuronal death in the brain [3,4], and other oligodendroglia-related disorders, such as multiple system atrophy (MSA) and Krabbe disease (KD). Mitochondria are key organelles for normal cellular functions and are involved in energy production, calcium homeostasis, as well as cell survival and mitochondrial injury. They were proposed to be the central pathogenesis of PD [5], MSA [6], KD [7], and some other NDDs [8,9]. Recently, the protein $\alpha$-synuclein is in the spotlight of the mechanism of mitochondrial injury in NDDs. Its abnormal accumulation and aggregation in mitochondria [10] impairs complex I and causes oxidative stress [11] in human dopaminergic neuronal cultures and the PD brain [12]. In contrast, fatty acid-binding proteins (FABPs) are the new pathological factors involved in $\alpha$-synuclein aggregation and migration in PD [13-15]. Importantly, some FABPs, such as FABP 1 [16], FABP 4 [17], and FABP 5 [18] are also localized in the mitochondria and are related to mitochondrial dysfunction.

In this review, we summarize the current data on the pathological functions of $\alpha$ synuclein and FABPs in NDDs and focus on the underlying relationship between their interactions and ability in mitochondrial injury. We further discuss the role of FABP inhibition in cell protection and provide some novel and critical perspectives on NDDtherapy-targeting mitochondria. 


\section{2. $\alpha$-Synuclein}

\section{1. $\alpha$-Synuclein Structure and Mutations}

$\alpha$-Synuclein is a low-molecular weight protein that is composed of 140 amino acids and is divided into three distinct regions-a positively charged N-terminal region (1-60), a central hydrophobic region (61-95), which is known as the non-amyloid-beta component (NAC) and is involved in $\alpha$-synuclein aggregation and a highly acidic C-terminal domain $(96-140)[19,20] . \alpha$-Synuclein is an intrinsically disordered protein abundantly expressed in the central nervous system (CNS) [21] and was first purified in vitro in soluble and monomeric forms [22]. Usually, disordered proteins possess primary sequences enriched in charged residues and prolines [23] that avoid misfolding and aggregation. In the case of $\alpha$-synuclein, the NAC domain is partially protected by the positive and negative charges of the $\mathrm{N}$ - and $\mathrm{C}$-terminal regions. However, mutations change their environmental conditions and disturb the native compactness of $\alpha$-synuclein, thereby triggering aggregation. To date, six point-mutations (A53T, A30P, A53E, E46K, G51D, and H50Q) of $\alpha$-synuclein were reported to be associated with synucleinopathies (Figure 1) [24-29]. Their rates of aggregation and oligomerization were studied widely in vitro [30-33]. Among them, $\alpha$-synuclein in E46K, H50Q, and A53T mutations are more prone to aggregation, while $\alpha$-synuclein in the A30P mutation appeared to be more prone to oligomerization [34]. All mutations identified to date are located in the $\mathrm{N}$-terminal domain but do not promote changes in the major structure to the $\alpha$-synuclein monomer. Only the A30P mutation suggested a reduced propensity to adopt alpha-helical content [35]. The membrane-binding properties of mutation types are likely affected by their localization in the N-terminal domain. For example, A53T and H50Q suggest a higher propensity to bind with membranes [36]; however, A30P, A53E, and G51D suggest a lower propensity to bind with membranes [37-39]. Additionally, these mutations alter long-range electrostatic interactions between the $\mathrm{N}$ - and $\mathrm{C}$-termini, thereby, affecting the stability of the native $\alpha$-synuclein [40]. Therefore, aberrant internal contacts of mutated $\alpha$-synuclein might cause a partially folded intermediate that increases the propensity for self-assembly [41].

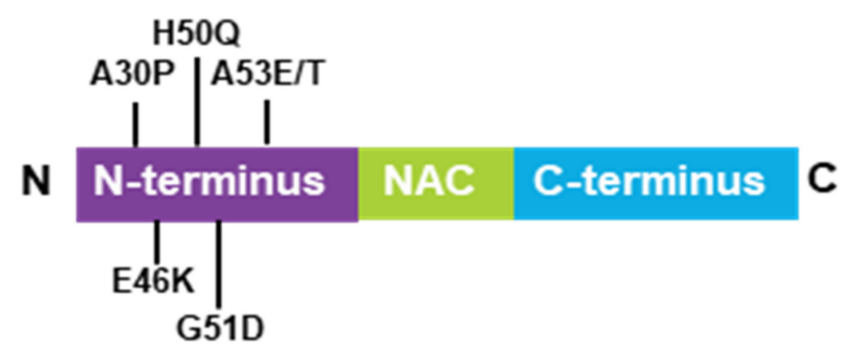

Figure 1. Schematic model of the $\alpha$-synuclein structure, containing the N-terminal domain, NAC, and the C-terminal domain. Six synucleinopathy-related point mutaions described so far.

\section{2. $\alpha$-Synuclein Oligomers and Neuronal Toxicity}

The definition of $\alpha$-synuclein oligomers is rather ambiguous, owing to their heterogeneity, instability, transient existence, and variability. Oligomers are regarded as intermediates of the aggregation process but suggest higher toxicity than the other forms [42-44] and cause a wide range of damaging effects, such as inhibition of exocytosis and dopamine release in PC12 cells [45], complex I-dependent, $\mathrm{Ca}^{2+}$-induced mitochondrial dysfunction in an in vitro system comprising isolated mitochondria [46], and altering synaptic transmission in primary hippocampal and dissociated nigral neurons [47]. Additionally, $\alpha$-synuclein oligomers can permeabilize lipid bilayers $[48,49]$ and alert plasma and intracellular membrane structures [50], by rearranging the lipid microenvironment and accelerating the flux of hydrophilic molecules in the surroundings [49,51]. On the other hand, $\alpha$-synuclein oligomers also induce pore formation and act as pathological membrane channels, while tubular amyloid or ring-shaped oligomers are integrated into the membrane [48,52]. Although $\alpha$-synuclein oligomers seem like they connect with plasma membrane in neurons, 
the structural characterization of the putative pores remains unclear. Furthermore, it was reported that $\alpha$-synuclein oligomers inhibit tubulin polymerization, affect the cytoskeleton of cells, and damage the integrity of the neurite network in a human dopaminergic cell line $[28,53]$. Similarly, $\alpha$-synuclein overexpression also causes microtubule destabilization and neuritic degeneration in cultured cells [54].

Misfolded and damaged polypeptides such as $\alpha$-synuclein oligomers and aggregates in PD are mainly degraded by two major protein degradation systems - the autophagylysosomal pathway (ALP) and the ubiquitin-proteasome system (UPS) [55]. However, in the brains of patients with PD, lysosomal activity [56] and various lysosomal markers (LAMP1, heat-shock protein 73, and cathepsin D) were significantly decreased, especially in nigral neurons containing $\alpha$-synuclein inclusions [57]. Consistently, dementia with Lewy body (DLB) brains also exhibits ALP depletion [58]. Additionally, $\alpha$-synuclein aggregates inhibit macroautophagy by binding with essential ALP components, such as p62 and LC3 [58]. In cultured cells, chaperone-mediated autophagy was inhibited by mutated $\alpha$-synuclein expression [59]. This inhibition results from $\alpha$-synuclein binding with the specific receptor on the lysosome LAMP2, which might induce $\alpha$-synuclein aggregation and injure the entire homeostasis of cells [60]. UPS dysfunction is also present in PD brains, such as decreased proteasome enzymatic activities and structural defects of proteasomes [61,62], and proteasome dysfunction is considered to be of primary or secondary consequence in a wide array of chronic neurodegenerative diseases [63-67]. As reported previously, both wild-type $\alpha$-synuclein and mutant $\alpha$ Syn (A53T) expression resulted in a time-dependent and significant decrease in proteasome dysfunction in cellular models, such as SH-SY5Y cells [68] and PC12 cells [69]. A possible hypothesis about UPS inhibition by $\alpha$-synuclein is the steric blocking of the proteasome machinery. Seventy percent of Lowy bodies, extracted from post-mortem DLB brains, are positive for 205 proteasome components [70]; more importantly, the 20S component was found in $\alpha$-synuclein aggregates extracted from pre-formed $\alpha$-synuclein fibrils-treated and $\alpha$-synuclein-expressing HEK293 cells [71] and the 26S proteasome was isolated together with $\alpha$-synuclein oligomers [72]. Additionally, aggregated proteins such as amyloid- $\beta$ [70], tau [73], and $\alpha$-synuclein [72] interact with and impair proteasome functions, and aggregated proteins such as $\alpha$-synuclein and tau oligomers impair 20s proteasome function through allosteric impairment of the substrate gate in the $20 \mathrm{~S}$ core particle and prevents the 19S regulatory particle from injecting substrates into the degradation chamber $[73,74]$. Altogether, these findings suggest that $\alpha$-synuclein, especially $\alpha$-synuclein oligomers, can block the UPS, thereby, damaging the clearance of other substrates and unbalancing proteostasis.

\section{3. $\alpha$-Synuclein and the Mitochondrial Surface}

The inherent ability of $\alpha$-synuclein to bind to lipids and membranes, especially membranes with negatively charged surfaces, increases the potential for interaction with the mitochondrial membrane [75]. Thus, the properties of $\alpha$-synuclein in lipid binding were extensively investigated [76]. Several studies indicated that the ability for $\alpha$-synuclein docking to the lipid surface is regulated by the deletion or insertion of charged amino groups in the first 25 residues of the N-terminal domain, adopting an $\alpha$-helix conformation [77-79]. Thus, some mutations of $\alpha$-synuclein, such as A30P, E46K, and A53T, in this domain might strongly affect this ability. Regarding the mitochondrial outer membrane (MOM) proteins, which $\alpha$-synuclein are associated with, the in vitro pulldown experiments of extracts of the mitochondria with $\alpha$-synuclein peptide composed of the last 40 residues of C-terminal retrieved TOM22, TOM40, voltage-dependent anion channels (VDAC)-1, 2, 3, and Samm50 as binding partners (Figure 2). However, the S129 phosphorylation distinctly inhibited $\alpha$-synuclein association with TOM40 and Samm50 [80]. VDAC is a vital and recurrent binding partner of $\alpha$-synuclein, and co-immunoprecipitation analysis revealed an association between the two proteins in the brainstem, striatum, and cerebral cortex in A53T human $\alpha$-synuclein transgenic mice [81]. Moreover, recombinant $\alpha$-synuclein 
monomers in vitro suggested marketable inhibition ability in the VDAC-1 channel activity in planar lipid bilayers [82].

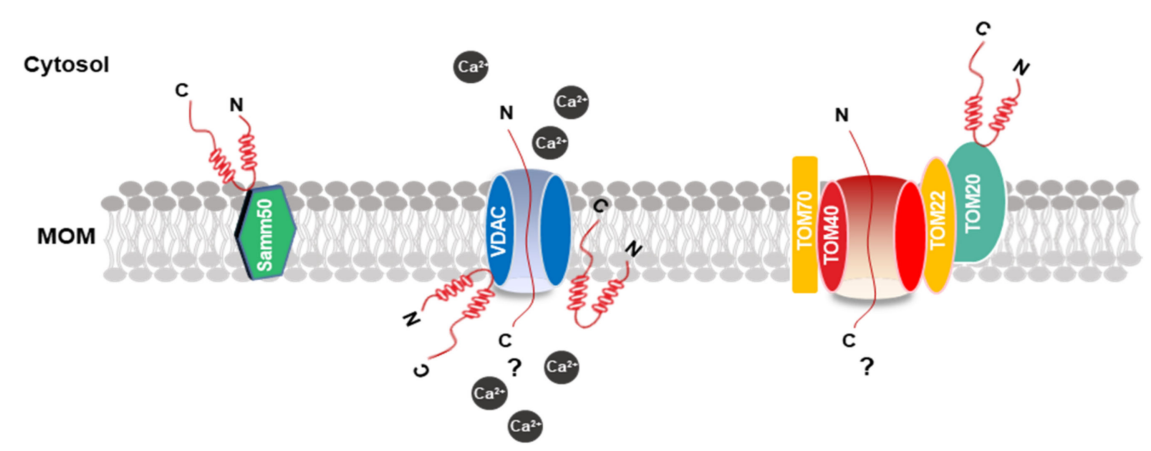

Figure 2. Schematic model of the MOM and $\alpha$-synuclein association. The picture shows $\alpha$-synuclein binding patterns at the MOM. Proteins that interact with $\alpha$-synuclein are highlighted in colors. The possible mechanism of $\alpha$-synuclein transport into the mitochondria through VDAC and TOM20. $\alpha$-synuclein is shown in red. MOM, mitochondrial outer membrane; VDAC, voltage-dependent anion channels.

Therefore, although $\alpha$-synuclein is the able to bind membranes directly, especially the proteins that mirror the composition of mitochondria, and the protein-protein interactions with the MOM were consistently reported, the mechanism for the mitochondrial protein import machinery, particularly TOM20, remains unclear.

\section{4. $\alpha$-Synuclein in Mitochondrial Injury}

The association between PD and mitochondria was reported in 1976; 1-Methyl-1,2,3,6tetrahydropiridine (MPTP) was discovered as a mitochondrial complex I inhibitor, resulting in PD-like motor symptoms. Furthermore, complex I activity decreased by approximately $30 \%$ to $40 \%$ in the substantia nigra pars compacta (SNpc) of patients with PD. This further supports the vital role of mitochondria in PD development [83]. In contrast, experimental rodent models and patients with PD indicated strong evidence of damage to mitochondrial dynamics and increased reactive oxygen species (ROS) [84,85]. The main PD-connected genes are involved in mitochondrial homeostasis. Mutations in these genes are associated with mitochondrial dysfunction and might cause familial PD, as reported elsewhere [84]. New findings also described the role of $\alpha$-synuclein in mitochondrial injury [86,87]. It is possible that there is a salient relationship between $\alpha$-synuclein and mitochondria under physiological or pathological conditions.

Recently, the toxicity of $\alpha$-synuclein in the mitochondria was extensively studied. Constitutive low $\alpha$-synuclein levels in the mitochondria might play an essential role in maintaining normal functions of mitochondrial complexes. However, high levels of $\alpha$ synuclein accumulation in the mitochondria contribute to the impairment of complex I function [12]. Furthermore, overexpression of wild-type or A53T mutant $\alpha$-synuclein in SHSY-5Y cells or treating aggregated $\alpha$-synuclein in an isolated mitochondrion, induces cytochrome $c$ release, thereby increasing mitochondrial oxidative stress and causing mitochondrial dysfunction and fragmentation $[11,87,88]$. Although the mechanism through which $\alpha$-synuclein translocates to the mitochondria remains unclear, the $\mathrm{N}$-terminal domain of $\alpha$-synuclein mimics mitochondrial-targeting sequence properties and contributes to the anchoring of $\alpha$-synuclein to the mitochondrial membrane [88]. Additionally, $\alpha$-synuclein suggested a high-affinity binding to the TOM20 pre-sequence receptor of the mitochondrial protein import machinery. When $\alpha$-synuclein translocates to the mitochondrial membrane, it disrupts the translocase of the inner and MOM complex assembly process and impairs mitochondrial protein import from the cytosol [87,89-91]. Interestingly, $\alpha$-synuclein also functions in the mitochondrial matrix, indicating that physiological $\alpha$-synuclein accelerates ATP synthase activity by directly binding to its subunit, thereby ensuring mitochondrial 
health and proper ATP fueling for synaptic function [87]. Ludtmann et al. reported that $\alpha$ synuclein monomers interact with and enhance ATP synthase under normal conditions [91]. Under pathological conditions, $\alpha$-synuclein aggregation is stimulated and generates accumulated $\alpha$-synuclein oligomers with increasing enrichment of $\beta$-sheet structures that are in close proximity to the inner mitochondrial membrane. They inhibit complex I function, thereby triggering oxidation events and ultimately leading to mega-channel opening and mitochondrial permeability transition events [91]. Therefore, $\alpha$-synuclein itself does not interfere with the normal functions of mitochondria, and the toxicity of $\alpha$-synuclein in the mitochondria is regulated by its oligomerization and aggregation events, which are associated with other pathological factors.

\section{FABPs}

\subsection{Expression and Functions of FABPs in the Brain}

In cells, fatty acids with a small number of carbon atoms are water-soluble; however, long-chain fatty acids with 12 or more carbon atoms are insoluble. Therefore, to move long-chain fatty acids inside the cells, an FABP that binds to and solubilizes long-chain fatty acids is required. The FABP family is a low-molecular-weight intracellular protein, with a molecular weight of $14-15 \mathrm{kDa}$, and up to 12 types of molecular species were identified in mammals [92]. They serve intracellular lipid chaperones and regulate the uptake and transportation of long-chain FAs $[93,94]$, such as eicosanoids and bile acids. Their functions are thought to include intracellular uptake of ligands, transport to lipid metabolism pathways, and regulation of lipid signal transduction [95]. FABP is named after the first isolated tissue or cell, heart-type (H-), brain-type (B-), epidermis-type (E-), adipocyte-type (A-), liver-type (L-), intestinal-type (I-) FABP, etc. However, due to the diversity of tissue and cell expression, they were recently called L-FABP (FABP1), I-FABP (FABP2), and H-FABP (FABP3), in the order of isolation.

Among them, three FABPs, the heart-type (FABP3), brain-type (FABP7), and epidermaltype (FABP5), are expressed in the brain. FABP7 localizes to the neural stem cells of astrocytes and the hippocampal granule cell layer. This suggests high expression levels in the embryonic brain after birth; however, the expression levels decrease in the mature brain, astrocytes, and OPCs [96,97]. This expression is localized in astrocytes and the hippocampal neural stem cells [98]. Analysis using FABP7 gene knock-out mice revealed that FABP7 is involved in n-3 long-chain unsaturated fatty acid uptake into astrocytes.

Interestingly, no abnormalities were observed in spatial memory and learning in FABP7-deficient mice, but aversive memory, fear, and anxiety were enhanced [96]. On the other hand, FABP5 is most widely expressed in the epidermis, liver, and adipocytes and is similar to FABP7. It is highly expressed in the nerve and glial cells in embryonic brains but is decreased in mature brains $[97,99,100]$. The expression of mRNA peaks from neurogenesis (E17) to the process of nerve differentiation (E19), and its expression decreases during the synaptogenesis period (P5-P10), suggesting that it is involved in the migration and differentiation of nerve cells [101]. On the other hand, FABP3 is not expressed in an embryonic brain but is expressed in nerve cells in a mature brain [99]. FABP3 was first isolated from the heart, although it is widely expressed in the tissues and cells in the body, it was reported to be expressed in the brain, skeletal muscle, mammary gland, and ovary, in addition to the heart. In contrast to FABP7, FABP3 has a high affinity for n- 6 unsaturated fatty acids, such as arachidonic acid [102]. It was also shown to bind to epoxyeicosatrienoic acid, an arachidonic acid metabolite, and to prolong its half-life [103]. Furthermore, it was reported that FABP3 expression is increased in the serum and cerebrospinal fluid (CSF) of patients with neurodegenerative disorders, including $\mathrm{PD}, \mathrm{AD}$, and other neurological disorders [104,105], suggesting that it might not only be related to normal brain function but also to neurological disease. 


\subsection{Functions of FABPs in Neurodegenerations}

\subsubsection{FABP3 in the Dopamine Nervous System}

The dopamine nervous system is deeply involved in the development of severe psychiatric disorders, such as schizophrenia and attention deficit hyperactivity disorder [106,107]. Most antipsychotics have a D2 receptor blocking effect, and blocking the striatal D2 receptor is effective in improving positive symptoms in schizophrenia [108]. The D2 receptor has two subtypes, D2L and D2S, which depend on the presence or absence of the 29 amino acid residues in the third loop in the cell [109]. D2L receptors are mainly expressed at the posterior synapses of the striatum and the marginal system, and D2S receptors are present as auto-receptors in the substantia nigra and dopaminergic nerve endings (pre-synapses) in the ventral tegmental area. Previously, we investigated the intracellular expression and signal transduction of the NG108-15 cells, which specifically express the D2L and D2S receptors [110-112]. Different localizations of D2L and D2S receptors were found, in which most D2S receptors are expressed on the cell membrane but the D2L receptor is strongly expressed around the inner core [112]. Using FABP3 knockout mice, it was found that FABP3 binds to the D2L receptor and regulates D2L receptor function in dopamine-related locomotor activity and motor coordination [113].

\subsubsection{FABP3 in $\alpha$-Synuclein Oligomerization and Migration}

FABP3 binds to the D2L receptor [113-115]. It suggests that FAPB3 plays potential regulatory functions in the dopamine nervous system related to the process of PD. Recently, the positive function of FABP3 in $\alpha$-synuclein accumulation was demonstrated. In the MPTPinduced mouse model of PD, FABP3 is implicated in MPTP-induced neuronal toxicity and $\alpha$-synuclein accumulation [13]. First, it was determined that FABP3 knockout mice were more resistant to MPTP toxicity and suggested weaker dopamine neuronal loss and motor deficits in a mouse PD model, as compared to wild-type mice. Then, enhanced $\alpha$-synuclein oligomerization in response to elevated FABP3 levels was observed; however, in FABP3 knockout mice, $\alpha$-synuclein oligomerization remained markedly decreased. Moreover, FABP3-mediated AA incorporation following neurotoxin exposure induces $\alpha$-synuclein oligomerization. Importantly, $\alpha$-synuclein binds to FABP3 directly via its $\mathrm{C}$-terminal region and enhances the formation of toxic oligomers (Figure 3) [116]. Additionally, inhibition of FABP3 by FABP3 ligands also significantly attenuated $\alpha$-synuclein oligomerization [117], dopamine neuronal loss, and behavioral impairments [118].

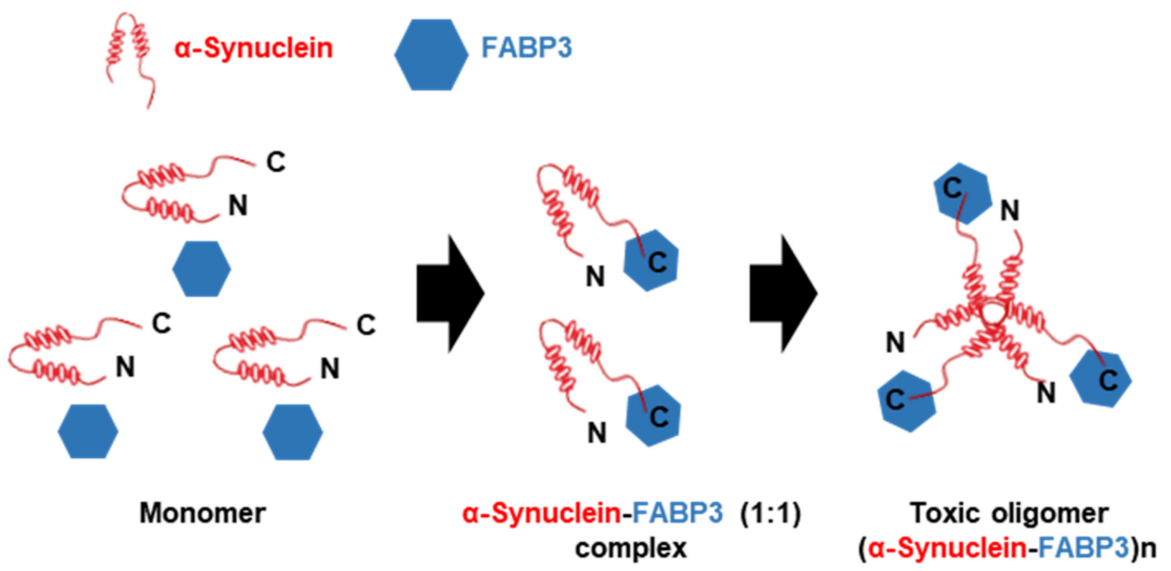

Figure 3. Schematic model of toxic $\alpha$-synuclein oligomerization with FABP3. $\alpha$-synuclein initially exhibits as a monomeric form in solution. However, in the presence of FABP3, $\alpha$-synuclein binds to FABP3 via its C-terminal region and forms a soluble $\alpha$-synuclein-FABP3 (1:1) complex. In addtion, the $\alpha$-synuclein-FABP3 complex changes over time to oligomeric forms, ( $\alpha$-synuclein-FABP3)n that displays cytotoxicity (modified from [116]). 
In contrast, FABP3 also plays critical roles in extracellular $\alpha$-synuclein monomer uptake and is critical for MPTP-induced neuronal retraction, mitochondrial function, and oxidative stress [14]. To elucidate the mechanism through which FABP3 mediates $\alpha$ synuclein uptake, mesencephalic neurons derived from dopamine D2L knockout mice, FABP3 knockout mice, and wild-type C57BL6 mice were employed and the ability of fluorescence-conjugated $\alpha$-synuclein monomers and fibrils uptake was measured in a previous study [119]. The physiological significance of D2L in $\alpha$-synuclein uptake in dopaminergic neurons in D2L knockout mice and wild-type C57BL6 mice was investigated and the uptake ability of ATTO-55O-labeled $\alpha$-synuclein monomers in D2L knockout neurons was observed. This demonstrated that the D2L receptor is vital for $\alpha$-synuclein uptake into dopaminergic neurons. Since dopamine D2 receptors are abundantly localized in membrane rafts [120] and internalized via the caveolae-mediated endocytic pathway [121], the cells were further treated with dynasore or interfered with caveolin-1 expression by caveolin-1 shRNA, thereby inhibiting the caveolar function. Abolished uptake of $\alpha-$ synuclein monomers after caveolar inhibition was found. As with $\alpha$-synuclein monomers, the uptake of $\alpha$-synuclein fibrils by FABP3 knockout mice and D2L knockout mice was also identified, and both FABP3 and D2L receptors were found to be vital for the uptake of $\alpha$-synuclein fibrils. The results indicated that dopamine D2L with a caveola structure, coupled with FABP3, plays an essential role in both $\alpha$-synuclein monomer and fibril uptake by dopaminergic neurons, suggesting a novel pathogenic mechanism of synucleinopathies, including PD [119].

\subsubsection{FABP5 in Cognitive Deficits}

Docosahexaenoic acid (DHA) is a vital n-3 polyunsaturated fatty acid in the brain, suggesting potent effects on cognition function, by regulating synaptic transmission and long-term potentiation in the hippocampus $[122,123]$. Due to the limited ability of the brain to synthesize its own DHA, DHA transports across the blood-brain barrier (BBB) to reach the brain $[124,125]$. In support of this pathway, FABP5 was reported to be a critical protein involved in the uptake of exogenous DHA [126]. Furthermore, a recent study also indicated that FABP5 is localized in the BBB and is essential for maintaining brain endothelial cell uptake of DHA, and FABP5 knockout mice suggested obvious cognitive deficits associated with decreased DHA levels in the brain [127]. On the other hand, another study indicated cognitive impairments in learning and memory in FABP5 knockout mice, which are related to diminished peroxisome proliferator-activated receptor (PPAR) $\beta / \delta$ activation by arachidonic acid [128].

On the other hand, in experimental autoimmune encephalomyelitis (EAE) in a mouse model of MS, the deficiency of FABP5 indicated a protective effect from the development of EAE $[129,130]$. Dendritic cells with FABP5 deficiency are defective in the production of proinflammatory cytokines and Th1 and Th17 responses [130]. In addition, FABP5 deficiency in CD4+ T cells exhibited increased expression levels of PPAR $\gamma$, which inhibited Th17 differentiation and enhanced regulatory T cell development [129]. Importantly, inhibition of FABP5 by inhibitors can regulate the functions of $\mathrm{T}$ cells and antigen-presenting cells, thereby ameliorating the clinical symptoms of EAE by inhibiting pathogenic processes and lymphocyte migration [131]. Importantly, in our recent study, we also found a tight connection between FABP5 and $\alpha$-synuclein [132]. In Neuro-2A cells treated with rotenone, $\alpha$-synuclein forms high molecular weight $\alpha$-synuclein oligomers, together with FABP5 in SDS-soluble fractions and triggers significant loss of cell viability. This might indicate a potential role of FABP5 in dopaminergic neuron loss in synucleinopathies.

\subsubsection{FABP5 in Mitochondrial Injury}

Mitochondria are critical organelles for fatty acid metabolism, and FABPs are chaperone proteins that bind hydrophobic ligands, thereby coordinating lipid uptake and intracellular trafficking [133]. Several previous studies demonstrated the critical roles of FABP5 in maintaining normal mitochondrial integrity and function, via regulation of lipid 
metabolism in Treg cells [134] and memory T cells [135]. However, in our recent study, we demonstrated a potential mechanism through which FABP5 might be connected with mitochondrial injury in neurodegeneration. In psychosine-treated (a critical biochemical pathogenetic mechanism of the loss of oligodendrocytes and myelin in KD) oligodendrocytes, we found abnormal accumulation of FABP5 in the mitochondria that formed macropores in the MOM associated with VDAC-1 and BCL-2-like protein 4 (BAX) [18]. Furthermore, along with macropore formation, inflammatory substances in mitochondria, such as mitochondrial DNA (mtDNA), cytochrome $C$ release to the cytosol, and trigger activation of cysteine proteases, thereby, causing cell death. These data indicate a potential role of FABP5 in inducing oligodendrocyte loss in KD (Figure 4).

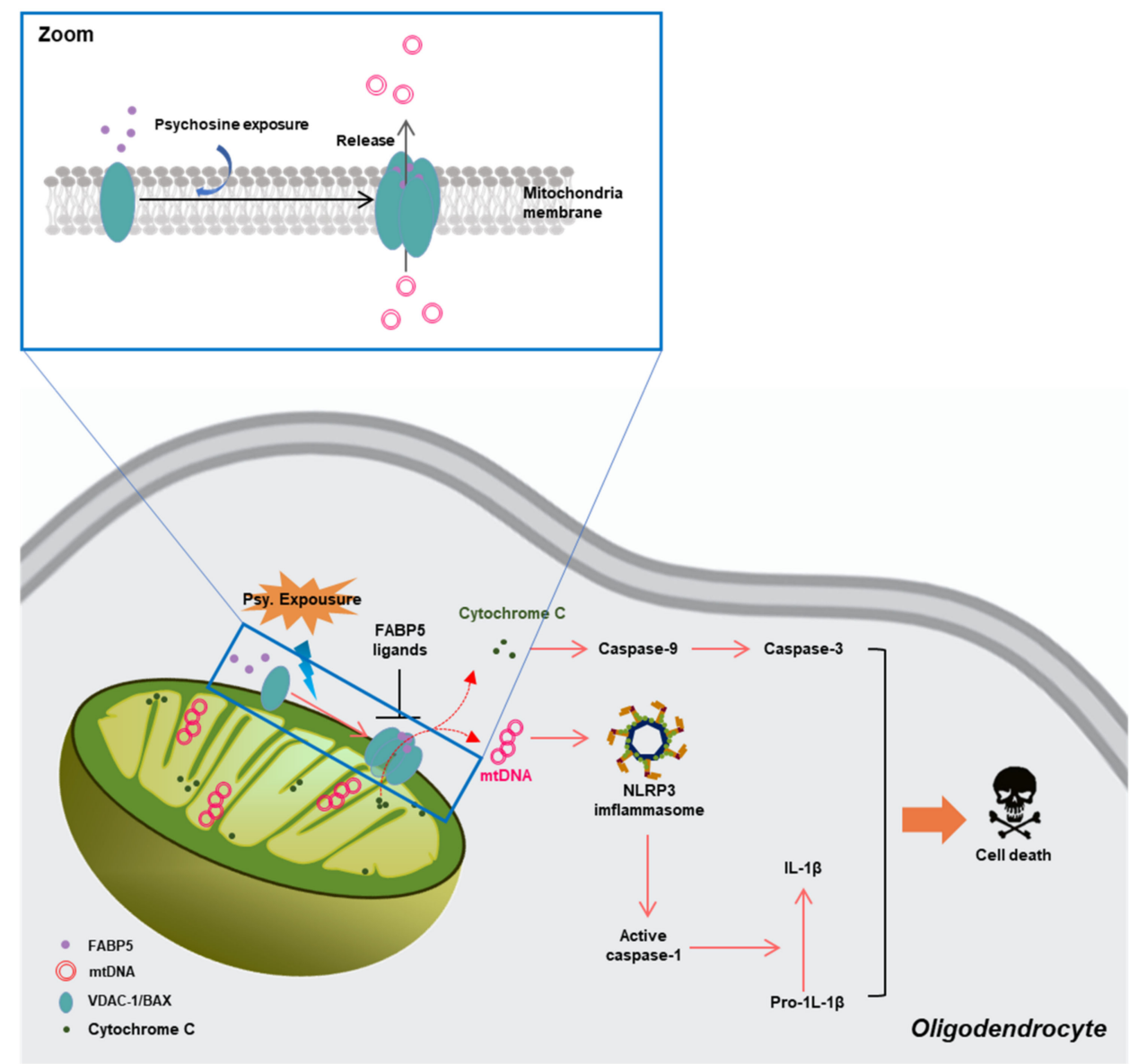

Figure 4. Schematic representation of the pathways through which FABP5 facilitates mitochondrial macropore formation and induces oligodendrocyte apoptosis [18]. FABP—fatty acid-binding proteins.

In our recent study, we also found that FABP5 normally localized in the mitochondria of Neuro-2A cells. Interestingly, FABP5 co-localized with $\alpha$-synuclein and formed heterooligomers and aggregates in $\alpha$-synuclein-overexpressing Neuro-2A cells treated with rotenone [132]. Furthermore, we also observed that rotenone treatment led to $\alpha$-synuclein aggregate localization in the mitochondria and decreased mitochondrial membrane potential, resulting in cell death [132]. This finding indicated that FABP5 is involved in mitochondrial injury associated with $\alpha$-synuclein in synucleinopathies.

\subsubsection{FABP7 in Neurodegenerations}

Several studies indicated that FABP7 is also associated with pathological processes in the CNS. In young adult monkeys, the expression levels of FABP7 increased in different hippocampal sub-regions in response to cerebral ischemia [136]. The transient, complete, and whole-brain ischemia model of adult monkeys, which was induced by clamping 
the innominate and left subclavian arteries for $20 \mathrm{~min}$, suggested elevated expression levels of FABP7 in the hippocampus and were co-localized to proliferating cells following ischemia. [137]. In addition, FABP7 expression is strongly upregulated and co-localized with GFAP expression in response to contusive spinal cord injury in mice [138]. On the other hand, in MOG-induced EAE mice, FABP7 and GFAP double-positive cells accumulated within the spinal cord [139], and FAB7 knockout mice exhibited attenuated clinical scores in the late phase of EAE [140].

\section{Novel Therapeutic Target to Mitochondrial Dysfunction via FABP Inhibition}

Although $\alpha$-synuclein monomers normally bind to the mitochondrial membrane, suggest tight interactions with ATP synthase, and improve ATP synthesis efficiency [91], some other reports also indicated the toxic effect of $\alpha$-synuclein monomers on mitochondria. In SHSY-5Y cells, both wild-type and A53T mutant $\alpha$-synuclein overexpression induced significant cytochrome $c$ release and mitochondrial calcium and nitric oxide increase [11]. However, the A53T mutant $\alpha$-synuclein monomers showed a higher tendency to localize to the mitochondrial membrane and higher toxicity than the wild-type [141]. In contrast, $\alpha$-synuclein translocated to the mitochondria in response to cellular stress and directly upon intracellular acidification [142], dysregulation of ion transport [143], hydrolysis of high-energy nucleotides [144], and the PD toxin $\mathrm{MPP}^{+}$impaired cellular energy metabolism and resulted in a decrease in $\mathrm{pH}$ [145]. The mutant $\alpha$-synuclein-like A53T is more prone to aggregation, attenuates oxidative stress [146,147], and interferes with iron homeostasis $[148,149]$. Inhibition of $\alpha$-synuclein aggregation is important for maintaining iron homeostasis and normal ROS and $\mathrm{pH}$ levels, thereby protecting the mitochondria from $\alpha$-synuclein toxicity in neurodegeneration. The inhibition of FABP3 by FABP3 ligands significantly disrupted $\alpha$-synuclein oligomerization and aggregation in both cultured Neuro-2A cells [117] and mouse models [118]. Furthermore, the inhibitor of FABP5 by FABP5 inhibitor also inhibited FABP5-dependent $\alpha$-synuclein oligomerization towards mitochondrial localization and toxicity [132].

In contrast, FABP5 is vital for macropore formation to interact with VDAC-1 oligomers and BAX, under psychosine stress [18]. Macropores are usually involved in the abnormal release of $\mathrm{mtDNA}$ and cytochrome $\mathrm{c}$, which are connected with the activation of the cGAS-STING pathway and mitochondrial damage [77]. We recently reported a novel FABP5 inhibitor, which suggested a high affinity for FABP5 and blocked FABP5-dependent VDAC-1 oligomerization, thus, inhibiting macropore formation. Furthermore, the FABP5 inhibitor also decreased cytochrome $\mathrm{c}$ release from mitochondria, attenuated the generation of inflammatory cytokine-like IL-1 $\beta$ in the cytosol, and rescued mitochondrial dysfunction in oligodendrocytes.

\section{Conclusions}

The etiology of NDD is likely multifactorial. Many factors might be involved in this, including mitochondrial dysfunction, clearance system injury (proteasome and lysosome dysfunction), endoplasmic reticulum stress, and interfered synapse transmission. Here, we reviewed the mitochondrial injury associated with $\alpha$-synuclein and FABPs in NDDs, and provided a novel therapeutic target for mitochondrial dysfunction.

$\alpha$-Synuclein is capable of binding to the MOM, directly by the N-terminal [77-79] and interaction with MOM proteins, such as TOM20 and VDAC-1. However, $\alpha$-synuclein binds to TOM20, which is involved in impairing the TOM20/TOM22 assembly, leading to injured respiration and ROS production [89]. Consistent with TOM20, VDAC-1/ $\alpha-$ synuclein association also inhibited VDAC-1 activity in vitro. In contrast, a recent study also reported a positive effect of $\alpha$-synuclein monomers on ATP production, and only the oligomeric forms are toxic to mitochondria [91]. Recently, several studies indicated the role of FABP3 and FABP5 in $\alpha$-synuclein oligomerization and migration, as well as triggering the loss of mitochondrial function in neurons $[13,14,118,135]$. Importantly, FABP5 is a vital protein that interacts with VDAC-1 and forms mitochondrial macropores under psychosine 
treatment [18]. Therefore, inhibition of FABP3 and FABP5 is novel and critical for the treatment of NDDs, which is attributed to mitochondrial injury.

In the present review, we summarized the molecular mechanism of $\alpha$-synuclein and its aggregation in neuronal toxicity and mitochondrial injury. We also reviewed a new protein family, FABPs, as risk factors for inducing $\alpha$-synuclein aggregation and mitochondrial injury. These insights might lead to more focused efforts to develop therapeutics and strategies to prevent the onset of NDDs targeting mitochondrial injury.

Author Contributions: A.C. original draft writing; W.J. review and editing; I.K. review and editing; K.F. supervision, review/editing, and funding. All authors have read and agreed to the published version of the manuscript.

Funding: This work was supported in part by the Strategic Research Program for Brain Sciences from Japan Agency for Medical Research and Development (JP17dm0107071, JP18dm0107071, JP19dm0107071, and JP20dm0107071) (to K.F.), and the Smoking Research Foundation (to I.K.).

Institutional Review Board Statement: Not applicable.

Informed Consent Statement: Not applicable.

Data Availability Statement: Not applicable.

Acknowledgments: We thank the Uehara Memorial Foundation for financial support.

Conflicts of Interest: The authors declare no conflict of interest.

\section{References}

1. Przedborski, S.; Vila, M.; Jackson-Lewis, V. Series Introduction: Neurodegeneration: What is it and where are we? J. Clin. Investig. 2003, 111, 3-10. [CrossRef] [PubMed]

2. Lee, Y.; Morrison, B.M.; Li, Y.; Lengacher, S.; Farah, M.H.; Hoffman, P.N.; Liu, Y.; Tsingalia, A.; Jin, L.; Zhang, P.W.; et al. Oligodendroglia metabolically support axons and contribute to neurodegeneration. Nature 2012, 487, 443-448. [CrossRef] [PubMed]

3. Lane, C.A.; Hardy, J.; Schott, J.M. Alzheimer's disease. Eur. J. Neurol. 2018, 25, 59-70. [CrossRef]

4. Hayes, M.T. Parkinson's Disease and Parkinsonism. Am. J. Med. 2019, 132, 802-807. [CrossRef] [PubMed]

5. Rocha, E.M.; De Miranda, B.; Sanders, L.H. Alpha-synuclein: Pathology, mitochondrial dysfunction and neuroinflammation in Parkinson's disease. Neurobiol. Dis. 2018, 109, 249-257. [CrossRef]

6. Kawamoto, Y.; Ayaki, T.; Urushitani, M.; Ito, H.; Takahashi, R. Activated caspase-9 immunoreactivity in glial and neuronal cytoplasmic inclusions in multiple system atrophy. Neurosci. Lett. 2016, 628, 207-212. [CrossRef] [PubMed]

7. Cooper, C.E.; Markus, M.; Seetulsingh, S.P.; Wrigglesworth, J.M. Kinetics of inhibition of purified and mitochondrial cytochrome c oxidase by psychosine (beta-galactosylsphingosine). Biochem. J. 1993, 290 (Pt 1), 139-144. [CrossRef]

8. Wang, W.; Zhao, F.; Ma, X.; Perry, G.; Zhu, X. Mitochondria dysfunction in the pathogenesis of Alzheimer's disease: Recent advances. Mol. Neurodegener. 2020, 15, 30. [CrossRef] [PubMed]

9. Hamilton, J.; Brustovetsky, T.; Brustovetsky, N. Oxidative metabolism and $\mathrm{Ca}^{2+}$ handling in striatal mitochondria from YAC128 mice, a model of Huntington's disease. Neurochem. Int. 2017, 109, 24-33. [CrossRef] [PubMed]

10. Shavali, S.; Brown-Borg, H.M.; Ebadi, M.; Porter, J. Mitochondrial localization of alpha-synuclein protein in alpha-synuclein overexpressing cells. Neurosci. Lett. 2008, 439, 125-128. [CrossRef] [PubMed]

11. Parihar, M.S.; Parihar, A.; Fujita, M.; Hashimoto, M.; Ghafourifar, P. Mitochondrial association of alpha-synuclein causes oxidative stress. Cell Mol. Life Sci. 2008, 65, 1272-1284. [CrossRef] [PubMed]

12. Devi, L.; Raghavendran, V.; Prabhu, B.M.; Avadhani, N.G.; Anandatheerthavarada, H.K. Mitochondrial import and accumulation of alpha-synuclein impair complex I in human dopaminergic neuronal cultures and Parkinson disease brain. J. Biol. Chem. 2008, 283, 9089-9100. [CrossRef]

13. Shioda, N.; Yabuki, Y.; Kobayashi, Y.; Onozato, M.; Owada, Y.; Fukunaga, K. FABP3 protein promotes alpha-synuclein oligomerization associated with 1-methyl-1,2,3,6-tetrahydropiridine-induced neurotoxicity. J. Biol. Chem. 2014, 289, 18957-18965. [CrossRef] [PubMed]

14. Kawahata, I.; Bousset, L.; Melki, R.; Fukunaga, K. Fatty Acid-Binding Protein 3 is Critical for alpha-Synuclein Uptake and MPP(+)-Induced Mitochondrial Dysfunction in Cultured Dopaminergic Neurons. Int. J. Mol. Sci. 2019, 20, 5358. [CrossRef]

15. Cheng, A.; Wang, Y.-f.; Shinoda, Y.; Kawahata, I.; Yamamoto, T.; Jia, W.-b.; Yamamoto, H.; Mizobata, T.; Kawata, Y.; Fukunaga, K. Fatty acid-binding protein 7 triggers $\alpha$-synuclein oligomerization in glial cells and oligodendrocytes associated with oxidative stress. Acta Pharmacol. Sin. 2021. [CrossRef] [PubMed] 
16. Kamijo-Ikemori, A.; Ichikawa, D.; Matsui, K.; Yokoyama, T.; Sugaya, T.; Kimura, K. [Urinary L-type fatty acid binding protein (L-FABP) as a new urinary biomarker promulgated by the Ministry of Health, Labour and Welfare in Japan]. Rinsho Byori. Jpn. J. Clin. Pathol. 2013, 61, 635-640.

17. Li, H.; Xiao, Y.; Tang, L.; Zhong, F.; Huang, G.; Xu, J.M.; Xu, A.M.; Dai, R.P.; Zhou, Z.G. Adipocyte Fatty Acid-Binding Protein Promotes Palmitate-Induced Mitochondrial Dysfunction and Apoptosis in Macrophages. Front. Immunol. 2018, 9, 81. [CrossRef] [PubMed]

18. Cheng, A.; Kawahata, I.; Fukunaga, K. Fatty Acid Binding Protein 5 Mediates Cell Death by Psychosine Exposure through Mitochondrial Macropores Formation in Oligodendrocytes. Biomedicines 2020, 8, 635. [CrossRef] [PubMed]

19. Bayer, T.A.; Jäkälä, P.; Hartmann, T.; Havas, L.; McLean, C.; Culvenor, J.G.; Li, Q.-X.; Masters, C.L.; Falkai, P.; Beyreuther, K. $\alpha$-Synuclein accumulates in Lewy bodies in Parkinson's disease and dementia with Lewy bodies but not in Alzheimer's disease $\beta$-amyloid plaque cores. Neurosci. Lett. 1999, 266, 213-216. [CrossRef]

20. Guardia-Laguarta, C.; Area-Gomez, E.; Rub, C.; Liu, Y.; Magrane, J.; Becker, D.; Voos, W.; Schon, E.A.; Przedborski, S. alphaSynuclein is localized to mitochondria-associated ER membranes. J. Neurosci. 2014, 34, 249-259. [CrossRef]

21. Fauvet, B.; Mbefo, M.K.; Fares, M.B.; Desobry, C.; Michael, S.; Ardah, M.T.; Tsika, E.; Coune, P.; Prudent, M.; Lion, N.; et al. alpha-Synuclein in central nervous system and from erythrocytes, mammalian cells, and Escherichia coli exists predominantly as disordered monomer. J. Biol. Chem. 2012, 287, 15345-15364. [CrossRef]

22. Uversky, V.N. A protein-chameleon: Conformational plasticity of alpha-synuclein, a disordered protein involved in neurodegenerative disorders. J. Biomol. Struct. Dyn. 2003, 21, 211-234. [CrossRef]

23. Radivojac, P.; Iakoucheva, L.M.; Oldfield, C.J.; Obradovic, Z.; Uversky, V.N.; Dunker, A.K. Intrinsic disorder and functional proteomics. Biophys. J. 2007, 92, 1439-1456. [CrossRef] [PubMed]

24. Polymeropoulos, M.H.; Lavedan, C.; Leroy, E.; Ide, S.E.; Dehejia, A.; Dutra, A.; Pike, B.; Root, H.; Rubenstein, J.; Boyer, R.; et al. Mutation in the alpha-synuclein gene identified in families with Parkinson's disease. Science 1997, 276, 2045-2047. [CrossRef] [PubMed]

25. Krüger, R.; Kuhn, W.; Müller, T.; Woitalla, D.; Graeber, M.; Kösel, S.; Przuntek, H.; Epplen, J.T.; Schöls, L.; Riess, O. Ala30Pro mutation in the gene encoding alpha-synuclein in Parkinson's disease. Nat. Genet. 1998, 18, 106-108. [CrossRef] [PubMed]

26. Zarranz, J.J.; Alegre, J.; Gómez-Esteban, J.C.; Lezcano, E.; Ros, R.; Ampuero, I.; Vidal, L.; Hoenicka, J.; Rodriguez, O.; Atarés, B.; et al. The new mutation, E46K, of alpha-synuclein causes Parkinson and Lewy body dementia. Ann. Neurol. 2004, 55, 164-173. [CrossRef]

27. Lesage, S.; Anheim, M.; Letournel, F.; Bousset, L.; Honoré, A.; Rozas, N.; Pieri, L.; Madiona, K.; Dürr, A.; Melki, R.; et al. G51D $\alpha$-synuclein mutation causes a novel parkinsonian-pyramidal syndrome. Ann. Neurol. 2013, 73, 459-471. [CrossRef]

28. Prots, I.; Veber, V.; Brey, S.; Campioni, S.; Buder, K.; Riek, R.; Böhm, K.J.; Winner, B. $\alpha$-Synuclein oligomers impair neuronal microtubule-kinesin interplay. J. Biol. Chem. 2013, 288, 21742-21754. [CrossRef] [PubMed]

29. Pasanen, P.; Myllykangas, L.; Siitonen, M.; Raunio, A.; Kaakkola, S.; Lyytinen, J.; Tienari, P.J.; Pöyhönen, M.; Paetau, A. Novel $\alpha$-synuclein mutation A53E associated with atypical multiple system atrophy and Parkinson's disease-type pathology. Neurobiol. Aging 2014, 35, 2180.e1-2180.e5. [CrossRef]

30. Conway, K.A.; Lee, S.J.; Rochet, J.C.; Ding, T.T.; Williamson, R.E.; Lansbury, P.T., Jr. Acceleration of oligomerization, not fibrillization, is a shared property of both alpha-synuclein mutations linked to early-onset Parkinson's disease: Implications for pathogenesis and therapy. Proc. Natl. Acad. Sci. USA 2000, 97, 571-576. [CrossRef]

31. Conway, K.A.; Lee, S.J.; Rochet, J.C.; Ding, T.T.; Harper, J.D.; Williamson, R.E.; Lansbury, P.T., Jr. Accelerated oligomerization by Parkinson's disease linked alpha-synuclein mutants. Ann. N. Y. Acad. Sci. 2000, 920, 42-45. [CrossRef]

32. Ghosh, D.; Singh, P.K.; Sahay, S.; Jha, N.N.; Jacob, R.S.; Sen, S.; Kumar, A.; Riek, R.; Maji, S.K. Structure based aggregation studies reveal the presence of helix-rich intermediate during $\alpha$-Synuclein aggregation. Sci. Rep. 2015, 5, 9228. [CrossRef] [PubMed]

33. Uversky, V.N.; Li, J.; Fink, A.L. Evidence for a partially folded intermediate in alpha-synuclein fibril formation. J. Biol. Chem. 2001, 276, 10737-10744. [CrossRef]

34. Villar-Pique, A.; Lopes da Fonseca, T.; Outeiro, T.F. Structure, function and toxicity of alpha-synuclein: The Bermuda triangle in synucleinopathies. J. Neurochem. 2016, 139 (Suppl. 1), 240-255. [CrossRef]

35. Bussell, R., Jr.; Eliezer, D. Residual structure and dynamics in Parkinson's disease-associated mutants of alpha-synuclein. J. Biol. Chem. 2001, 276, 45996-46003. [CrossRef]

36. Tsigelny, I.F.; Sharikov, Y.; Kouznetsova, V.L.; Greenberg, J.P.; Wrasidlo, W.; Overk, C.; Gonzalez, T.; Trejo, M.; Spencer, B.; Kosberg, K.; et al. Molecular determinants of $\alpha$-synuclein mutants' oligomerization and membrane interactions. ACS Chem. Neurosci. 2015, 6, 403-416. [CrossRef]

37. Jo, E.; Fuller, N.; Rand, R.P.; St George-Hyslop, P.; Fraser, P.E. Defective membrane interactions of familial Parkinson's disease mutant A30P alpha-synuclein. J. Mol. Biol. 2002, 315, 799-807. [CrossRef]

38. Fares, M.B.; Ait-Bouziad, N.; Dikiy, I.; Mbefo, M.K.; Jovičić, A.; Kiely, A.; Holton, J.L.; Lee, S.J.; Gitler, A.D.; Eliezer, D.; et al. The novel Parkinson's disease linked mutation G51D attenuates in vitro aggregation and membrane binding of $\alpha$-synuclein, and enhances its secretion and nuclear localization in cells. Hum. Mol. Genet. 2014, 23, 4491-4509. [CrossRef] [PubMed]

39. Ghosh, D.; Sahay, S.; Ranjan, P.; Salot, S.; Mohite, G.M.; Singh, P.K.; Dwivedi, S.; Carvalho, E.; Banerjee, R.; Kumar, A.; et al. The newly discovered Parkinson's disease associated Finnish mutation (A53E) attenuates $\alpha$-synuclein aggregation and membrane binding. Biochemistry 2014, 53, 6419-6421. [CrossRef] [PubMed] 
40. Bertoncini, C.W.; Fernandez, C.O.; Griesinger, C.; Jovin, T.M.; Zweckstetter, M. Familial mutants of alpha-synuclein with increased neurotoxicity have a destabilized conformation. J. Biol. Chem. 2005, 280, 30649-30652. [CrossRef] [PubMed]

41. Sahay, S.; Ghosh, D.; Dwivedi, S.; Anoop, A.; Mohite, G.M.; Kombrabail, M.; Krishnamoorthy, G.; Maji, S.K. Familial Parkinson disease-associated mutations alter the site-specific microenvironment and dynamics of $\alpha$-synuclein. J. Biol. Chem. 2015, 290, 7804-7822. [CrossRef]

42. Karpinar, D.P.; Balija, M.B.; Kugler, S.; Opazo, F.; Rezaei-Ghaleh, N.; Wender, N.; Kim, H.Y.; Taschenberger, G.; Falkenburger, B.H.; Heise, H.; et al. Pre-fibrillar alpha-synuclein variants with impaired beta-structure increase neurotoxicity in Parkinson's disease models. EMBO J. 2009, 28, 3256-3268. [CrossRef]

43. Prots, I.; Grosch, J.; Brazdis, R.M.; Simmnacher, K.; Veber, V.; Havlicek, S.; Hannappel, C.; Krach, F.; Krumbiegel, M.; Schutz, O.; et al. alpha-Synuclein oligomers induce early axonal dysfunction in human iPSC-based models of synucleinopathies. Proc. Natl. Acad. Sci. USA 2018, 115, 7813-7818. [CrossRef]

44. Rockenstein, E.; Nuber, S.; Overk, C.R.; Ubhi, K.; Mante, M.; Patrick, C.; Adame, A.; Trejo-Morales, M.; Gerez, J.; Picotti, P.; et al. Accumulation of oligomer-prone alpha-synuclein exacerbates synaptic and neuronal degeneration in vivo. Brain 2014, 137, 1496-1513. [CrossRef]

45. Choi, B.K.; Choi, M.G.; Kim, J.Y.; Yang, Y.; Lai, Y.; Kweon, D.H.; Lee, N.K.; Shin, Y.K. Large alpha-synuclein oligomers inhibit neuronal SNARE-mediated vesicle docking. Proc. Natl. Acad. Sci. USA 2013, 110, 4087-4092. [CrossRef]

46. Luth, E.S.; Stavrovskaya, I.G.; Bartels, T.; Kristal, B.S.; Selkoe, D.J. Soluble, prefibrillar alpha-synuclein oligomers promote complex I-dependent, Ca2+-induced mitochondrial dysfunction. J. Biol. Chem. 2014, 289, 21490-21507. [CrossRef] [PubMed]

47. Pacheco, C.R.; Morales, C.N.; Ramirez, A.E.; Munoz, F.J.; Gallegos, S.S.; Caviedes, P.A.; Aguayo, L.G.; Opazo, C.M. Extracellular alpha-synuclein alters synaptic transmission in brain neurons by perforating the neuronal plasma membrane. J. Neurochem. 2015, 132, 731-741. [CrossRef]

48. Volles, M.J.; Lansbury, P.T., Jr. Vesicle permeabilization by protofibrillar alpha-synuclein is sensitive to Parkinson's disease-linked mutations and occurs by a pore-like mechanism. Biochemistry 2002, 41, 4595-4602. [CrossRef]

49. Van Rooijen, B.D.; Claessens, M.M.; Subramaniam, V. Membrane Permeabilization by Oligomeric $\alpha$-Synuclein: In Search of the Mechanism. PLoS ONE 2010, 5, e14292. [CrossRef]

50. Melachroinou, K.; Xilouri, M.; Emmanouilidou, E.; Masgrau, R.; Papazafiri, P.; Stefanis, L.; Vekrellis, K. Deregulation of calcium homeostasis mediates secreted $\alpha$-synuclein-induced neurotoxicity. Neurobiol. Aging 2013, 34, 2853-2865. [CrossRef]

51. Stöckl, M.; Claessens, M.M.; Subramaniam, V. Kinetic measurements give new insights into lipid membrane permeabilization by $\alpha$-synuclein oligomers. Mol. Biosyst. 2012, 8, 338-345. [CrossRef] [PubMed]

52. Tosatto, L.; Andrighetti, A.O.; Plotegher, N.; Antonini, V.; Tessari, I.; Ricci, L.; Bubacco, L.; Dalla Serra, M. Alpha-synuclein pore forming activity upon membrane association. Biochim. Biophys. Acta 2012, 1818, 2876-2883. [CrossRef]

53. Chen, L.; Jin, J.; Davis, J.; Zhou, Y.; Wang, Y.; Liu, J.; Lockhart, P.J.; Zhang, J. Oligomeric alpha-synuclein inhibits tubulin polymerization. Biochem. Biophys. Res. Commun. 2007, 356, 548-553. [CrossRef] [PubMed]

54. Lee, H.J.; Khoshaghideh, F.; Lee, S.; Lee, S.J. Impairment of microtubule-dependent trafficking by overexpression of alphasynuclein. Eur. J. Neurosci. 2006, 24, 3153-3162. [CrossRef]

55. Xilouri, M.; Brekk, O.R.; Stefanis, L. $\alpha$-Synuclein and protein degradation systems: A reciprocal relationship. Mol. Neurobiol. 2013, 47, 537-551. [CrossRef]

56. Dehay, B.; Bové, J.; Rodríguez-Muela, N.; Perier, C.; Recasens, A.; Boya, P.; Vila, M. Pathogenic lysosomal depletion in Parkinson's disease. J. Neurosci. 2010, 30, 12535-12544. [CrossRef]

57. Chu, Y.; Dodiya, H.; Aebischer, P.; Olanow, C.W.; Kordower, J.H. Alterations in lysosomal and proteasomal markers in Parkinson's disease: Relationship to alpha-synuclein inclusions. Neurobiol. Dis. 2009, 35, 385-398. [CrossRef]

58. Crews, L.; Spencer, B.; Desplats, P.; Patrick, C.; Paulino, A.; Rockenstein, E.; Hansen, L.; Adame, A.; Galasko, D.; Masliah, E. Selective molecular alterations in the autophagy pathway in patients with Lewy body disease and in models of alphasynucleinopathy. PLoS ONE 2010, 5, e9313. [CrossRef]

59. Xilouri, M.; Vogiatzi, T.; Vekrellis, K.; Park, D.; Stefanis, L. Abberant alpha-synuclein confers toxicity to neurons in part through inhibition of chaperone-mediated autophagy. PLoL ONE 2009, 4, e5515. [CrossRef]

60. Cuervo, A.M.; Stefanis, L.; Fredenburg, R.; Lansbury, P.T.; Sulzer, D. Impaired degradation of mutant alpha-synuclein by chaperone-mediated autophagy. Science 2004, 305, 1292-1295. [CrossRef]

61. McNaught, K.S.; Jenner, P. Proteasomal function is impaired in substantia nigra in Parkinson's disease. Neurosci. Lett. 2001, 297, 191-194. [CrossRef]

62. McNaught, K.S.; Belizaire, R.; Jenner, P.; Olanow, C.W.; Isacson, O. Selective loss of 20 S proteasome alpha-subunits in the substantia nigra pars compacta in Parkinson's disease. Neurosci. Lett. 2002, 326, 155-158. [CrossRef]

63. Furukawa, Y.; Vigouroux, S.; Wong, H.; Guttman, M.; Rajput, A.H.; Ang, L.; Briand, M.; Kish, S.J.; Briand, Y. Brain proteasomal function in sporadic Parkinson's disease and related disorders. Ann. Neurol. 2002, 51, 779-782. [CrossRef] [PubMed]

64. Ciechanover, A.; Brundin, P. The ubiquitin proteasome system in neurodegenerative diseases: Sometimes the chicken, sometimes the egg. Neuron 2003, 40, 427-446. [CrossRef]

65. Rubinsztein, D.C. The roles of intracellular protein-degradation pathways in neurodegeneration. Nature 2006, 443, 780-786. [CrossRef] [PubMed] 
66. Keller, J.N.; Hanni, K.B.; Markesbery, W.R. Impaired proteasome function in Alzheimer's disease. J. Neurochem. 2000, 75, 436-439. [CrossRef]

67. McNaught, K.S.; Olanow, C.W.; Halliwell, B.; Isacson, O.; Jenner, P. Failure of the ubiquitin-proteasome system in Parkinson's disease. Nat. Rev. Neurosci. 2001, 2, 589-594. [CrossRef]

68. Zondler, L.; Kostka, M.; Garidel, P.; Heinzelmann, U.; Hengerer, B.; Mayer, B.; Weishaupt, J.H.; Gillardon, F.; Danzer, K.M Proteasome impairment by $\alpha$-synuclein. PLoS ONE 2017, 12, e0184040. [CrossRef] [PubMed]

69. Tanaka, Y.; Engelender, S.; Igarashi, S.; Rao, R.K.; Wanner, T.; Tanzi, R.E.; Sawa, A.; Valina, L.D.; Dawson, T.M.; Ross, C.A. Inducible expression of mutant alpha-synuclein decreases proteasome activity and increases sensitivity to mitochondria-dependent apoptosis. Hum. Mol. Genet. 2001, 10, 919-926. [CrossRef] [PubMed]

70. Lindersson, E.; Beedholm, R.; Højrup, P.; Moos, T.; Gai, W.; Hendil, K.B.; Jensen, P.H. Proteasomal inhibition by alpha-synuclein filaments and oligomers. J. Biol. Chem. 2004, 279, 12924-12934. [CrossRef]

71. Tanik, S.A.; Schultheiss, C.E.; Volpicelli-Daley, L.A.; Brunden, K.R.; Lee, V.M. Lewy body-like alpha-synuclein aggregates resist degradation and impair macroautophagy. J. Biol. Chem. 2013, 288, 15194-15210. [CrossRef]

72. Emmanouilidou, E.; Stefanis, L.; Vekrellis, K. Cell-produced alpha-synuclein oligomers are targeted to, and impair, the 26S proteasome. Neurobiol. Aging 2010, 31, 953-968. [CrossRef] [PubMed]

73. Deger, J.M.; Gerson, J.E.; Kayed, R. The interrelationship of proteasome impairment and oligomeric intermediates in neurodegeneration. Aging Cell 2015, 14, 715-724. [CrossRef] [PubMed]

74. Thibaudeau, T.A.; Anderson, R.T.; Smith, D.M. A common mechanism of proteasome impairment by neurodegenerative disease-associated oligomers. Nat. Commun. 2018, 9, 1097. [CrossRef] [PubMed]

75. Shvadchak, V.V.; Yushchenko, D.A.; Pievo, R.; Jovin, T.M. The mode of $\alpha$-synuclein binding to membranes depends on lipid composition and lipid to protein ratio. FEBS Lett. 2011, 585, 3513-3519. [CrossRef] [PubMed]

76. Rhoades, E.; Ramlall, T.F.; Webb, W.W.; Eliezer, D. Quantification of alpha-synuclein binding to lipid vesicles using fluorescence correlation spectroscopy. Biophys. J. 2006, 90, 4692-4700. [CrossRef]

77. Maekawa, H.; Inoue, T.; Ouchi, H.; Jao, T.M.; Inoue, R.; Nishi, H.; Fujii, R.; Ishidate, F.; Tanaka, T.; Tanaka, Y.; et al. Mitochondrial Damage Causes Inflammation via cGAS-STING Signaling in Acute Kidney Injury. Cell Rep. 2019, 29, 1261-1273.e6. [CrossRef]

78. Perrin, R.J.; Woods, W.S.; Clayton, D.F.; George, J.M. Interaction of human alpha-Synuclein and Parkinson's disease variants with phospholipids. Structural analysis using site-directed mutagenesis. J. Biol. Chem. 2000, 275, 34393-34398. [CrossRef]

79. Bartels, T.; Ahlstrom, L.S.; Leftin, A.; Kamp, F.; Haass, C.; Brown, M.F.; Beyer, K. The N-terminus of the intrinsically disordered protein $\alpha$-synuclein triggers membrane binding and helix folding. Biophys. J. 2010, 99, 2116-2124. [CrossRef]

80. McFarland, M.A.; Ellis, C.E.; Markey, S.P.; Nussbaum, R.L. Proteomics analysis identifies phosphorylation-dependent alphasynuclein protein interactions. Mol. Cell. Proteom. MCP 2008, 7, 2123-2137. [CrossRef]

81. Martin, L.J.; Semenkow, S.; Hanaford, A.; Wong, M. Mitochondrial permeability transition pore regulates Parkinson's disease development in mutant $\alpha$-synuclein transgenic mice. Neurobiol. Aging 2014, 35, 1132-1152. [CrossRef]

82. Rostovtseva, T.K.; Gurnev, P.A.; Protchenko, O.; Hoogerheide, D.P.; Yap, T.L.; Philpott, C.C.; Lee, J.C.; Bezrukov, S.M. $\alpha$-Synuclein Shows High Affinity Interaction with Voltage-dependent Anion Channel, Suggesting Mechanisms of Mitochondrial Regulation and Toxicity in Parkinson Disease. J. Biol. Chem. 2015, 290, 18467-18477. [CrossRef] [PubMed]

83. Telford, J.E.; Kilbride, S.M.; Davey, G.P. Complex I is rate-limiting for oxygen consumption in the nerve terminal. J. Biol. Chem. 2009, 284, 9109-9114. [CrossRef] [PubMed]

84. Ryan, B.J.; Hoek, S.; Fon, E.A.; Wade-Martins, R. Mitochondrial dysfunction and mitophagy in Parkinson's: From familial to sporadic disease. Trends Biochem. Sci. 2015, 40, 200-210. [CrossRef] [PubMed]

85. Winklhofer, K.F.; Haass, C. Mitochondrial dysfunction in Parkinson's disease. Biochim. Biophys. Acta 2010, 1802, 29-44. [CrossRef]

86. Ludtmann, M.H.; Angelova, P.R.; Ninkina, N.N.; Gandhi, S.; Buchman, V.L.; Abramov, A.Y. Monomeric Alpha-Synuclein Exerts a Physiological Role on Brain ATP Synthase. J. Neurosci. 2016, 36, 10510-10521. [CrossRef]

87. Di Maio, R.; Barrett, P.J.; Hoffman, E.K.; Barrett, C.W.; Zharikov, A.; Borah, A.; Hu, X.; McCoy, J.; Chu, C.T.; Burton, E.A.; et al. alpha-Synuclein binds to TOM20 and inhibits mitochondrial protein import in Parkinson's disease. Sci. Transl. Med. 2016, 8 , 342ra378. [CrossRef]

88. Miraglia, F.; Ricci, A.; Rota, L.; Colla, E. Subcellular localization of alpha-synuclein aggregates and their interaction with membranes. Neural Regen. Res. 2018, 13, 1136-1144. [CrossRef]

89. Vicario, M.; Cieri, D.; Brini, M.; Cali, T. The Close Encounter Between Alpha-Synuclein and Mitochondria. Front. Neurosci. 2018, 12, 388. [CrossRef]

90. Hosios, A.M.; Manning, B.D. Lysosomal catch-and-release controls mTORC1. Nat. Cell Biol. 2018, 20, 996-997. [CrossRef]

91. Ludtmann, M.H.R.; Angelova, P.R.; Horrocks, M.H.; Choi, M.L.; Rodrigues, M.; Baev, A.Y.; Berezhnov, A.V.; Yao, Z.; Little, D.; Banushi, B.; et al. alpha-synuclein oligomers interact with ATP synthase and open the permeability transition pore in Parkinson's disease. Nat. Commun. 2018, 9, 2293. [CrossRef] [PubMed]

92. Veerkamp, J.H.; Peeters, R.A.; Maatman, R.G. Structural and functional features of different types of cytoplasmic fatty acid-binding proteins. Biochim. Biophys. Acta 1991, 1081, 1-24. [CrossRef]

93. Coe, N.R.; Bernlohr, D.A. Physiological properties and functions of intracellular fatty acid-binding proteins. Biochim. Biophys. Acta 1998, 1391, 287-306. [CrossRef] 
94. Spener, F.; Börchers, T.; Mukherjea, M. On the role of fatty acid binding proteins in fatty acid transport and metabolism. FEBS Lett. 1989, 244, 1-5. [CrossRef]

95. Glatz, J.F.; Vork, M.M.; Cistola, D.P.; van der Vusse, G.J. Cytoplasmic fatty acid binding protein: Significance for intracellular transport of fatty acids and putative role on signal transduction pathways. Prostaglandins Leukot. Essent. Fat. Acids 1993, 48, 33-41. [CrossRef]

96. Owada, Y.; Abdelwahab, S.A.; Kitanaka, N.; Sakagami, H.; Takano, H.; Sugitani, Y.; Sugawara, M.; Kawashima, H.; Kiso, Y.; Mobarakeh, J.I.; et al. Altered emotional behavioral responses in mice lacking brain-type fatty acid-binding protein gene. Eur. J. Neurosci. 2006, 24, 175-187. [CrossRef]

97. Storch, J.; Corsico, B. The emerging functions and mechanisms of mammalian fatty acid-binding proteins. Annu. Rev. Nutr. 2008, 28, 73-95. [CrossRef]

98. Owada, Y.; Yoshimoto, T.; Kondo, H. Spatio-temporally differential expression of genes for three members of fatty acid binding proteins in developing and mature rat brains. J. Chem. Neuroanat. 1996, 12, 113-122. [CrossRef]

99. Liu, R.Z.; Mita, R.; Beaulieu, M.; Gao, Z.; Godbout, R. Fatty acid binding proteins in brain development and disease. Int. J. Dev. Biol. 2010, 54, 1229-1239. [CrossRef]

100. Umaru, B.A.; Kagawa, Y.; Shil, S.K.; Arakawa, N.; Pan, Y.; Miyazaki, H.; Kobayashi, S.; Yang, S.; Cheng, A.; Wang, Y.; et al. Ligand Bound Fatty Acid Binding Protein 7 (FABP7) Drives Melanoma Cell Proliferation Via Modulation of Wnt/ $\beta$-Catenin Signaling. Pharm. Res. 2021, 38, 479-490. [CrossRef]

101. Liu, Y.; Longo, L.D.; De León, M. In situ and immunocytochemical localization of E-FABP mRNA and protein during neuronal migration and differentiation in the rat brain. Brain Res. 2000, 852, 16-27. [CrossRef]

102. Myers-Payne, S.C.; Hubbell, T.; Pu, L.; Schnütgen, F.; Börchers, T.; Wood, W.G.; Spener, F.; Schroeder, F. Isolation and characterization of two fatty acid binding proteins from mouse brain. J. Neurochem. 1996, 66, 1648-1656. [CrossRef] [PubMed]

103. Widstrom, R.L.; Norris, A.W.; Van Der Veer, J.; Spector, A.A. Fatty acid-binding proteins inhibit hydration of epoxyeicosatrienoic acids by soluble epoxide hydrolase. Biochemistry 2003, 42, 11762-11767. [CrossRef] [PubMed]

104. Mollenhauer, B.; Steinacker, P.; Bahn, E.; Bibl, M.; Brechlin, P.; Schlossmacher, M.G.; Locascio, J.J.; Wiltfang, J.; Kretzschmar, H.A.; Poser, S.; et al. Serum heart-type fatty acid-binding protein and cerebrospinal fluid tau: Marker candidates for dementia with Lewy bodies. Neuro-Degener. Dis. 2007, 4, 366-375. [CrossRef]

105. Teunissen, C.E.; Veerhuis, R.; De Vente, J.; Verhey, F.R.; Vreeling, F.; van Boxtel, M.P.; Glatz, J.F.; Pelsers, M.A. Brain-specific fatty acid-binding protein is elevated in serum of patients with dementia-related diseases. Eur. J. Neurol. 2011, 18, 865-871. [CrossRef]

106. Grace, A.A. Dysregulation of the dopamine system in the pathophysiology of schizophrenia and depression. Nat. Rev. Neurosci. 2016, 17, 524-532. [CrossRef]

107. Vosberg, D.E.; Leyton, M.; Flores, C. The Netrin-1/DCC guidance system: Dopamine pathway maturation and psychiatric disorders emerging in adolescence. Mol. Psychiatry 2020, 25, 297-307. [CrossRef]

108. Correll, C.U.; Kane, J.M.; Citrome, L.L. Epidemiology, Prevention, and Assessment of Tardive Dyskinesia and Advances in Treatment. J. Clin. Psychiatry 2017, 78, 1136-1147. [CrossRef]

109. Missale, C.; Nash, S.R.; Robinson, S.W.; Jaber, M.; Caron, M.G. Dopamine receptors: From structure to function. Physiol. Rev. 1998, 78, 189-225. [CrossRef]

110. Takeuchi, Y.; Fukunaga, K. Different activation of NF-kappaB by stimulation of dopamine D2L and D2S receptors through calcineurin activation. J. Neurochem. 2004, 90, 155-163. [CrossRef]

111. Takeuchi, Y.; Fukunaga, K. Dopamine D2 receptor activates extracellular signal-regulated kinase through the specific region in the third cytoplasmic loop. J. Neurochem. 2004, 89, 1498-1507. [CrossRef] [PubMed]

112. Takeuchi, Y.; Fukunaga, K. Differential subcellular localization of two dopamine D2 receptor isoforms in transfected NG108-15 cells. J. Neurochem. 2003, 85, 1064-1074. [CrossRef] [PubMed]

113. Shioda, N.; Yamamoto, Y.; Watanabe, M.; Binas, B.; Owada, Y.; Fukunaga, K. Heart-type fatty acid binding protein regulates dopamine D2 receptor function in mouse brain. J. Neurosci. 2010, 30, 3146-3155. [CrossRef]

114. Jia, W.; Wilar, G.; Kawahata, I.; Cheng, A.; Fukunaga, K. Impaired Acquisition of Nicotine-Induced Conditioned Place Preference in Fatty Acid-Binding Protein 3 Null Mice. Mol. Neurobiol. 2021. [CrossRef] [PubMed]

115. Jia, W.; Kawahata, I.; Cheng, A.; Fukunaga, K. The Role of CaMKII and ERK Signaling in Addiction. Int. J. Mol. Sci. 2021, 22, 3189. [CrossRef]

116. Fukui, N.; Yamamoto, H.; Miyabe, M.; Aoyama, Y.; Hongo, K.; Mizobata, T.; Kawahata, I.; Yabuki, Y.; Shinoda, Y.; Fukunaga, K.; et al. An alpha-synuclein decoy peptide prevents cytotoxic alpha-synuclein aggregation caused by fatty acid binding protein 3. J. Biol. Chem. 2021. [CrossRef]

117. Cheng, A.; Shinoda, Y.; Yamamoto, T.; Miyachi, H.; Fukunaga, K. Development of FABP3 ligands that inhibit arachidonic acid-induced $\alpha$-synuclein oligomerization. Brain Res. 2019, 1707, 190-197. [CrossRef] [PubMed]

118. Matsuo, K.; Cheng, A.; Yabuki, Y.; Takahata, I.; Miyachi, H.; Fukunaga, K. Inhibition of MPTP-induced alpha-synuclein oligomerization by fatty acid-binding protein 3 ligand in MPTP-treated mice. Neuropharmacology 2019, 150, 164-174. [CrossRef]

119. Kawahata, I.; Sekimori, T.; Wang, H.; Wang, Y.; Sasaoka, T.; Bousset, L.; Melki, R.; Mizobata, T.; Kawata, Y.; Fukunaga, K. Dopamine D2 Long Receptors Are Critical for Caveolae-Mediated alpha-Synuclein Uptake in Cultured Dopaminergic Neurons. Biomedicines 2021, 9, 49. [CrossRef] [PubMed] 
120. Sharma, M.; Celver, J.; Octeau, J.C.; Kovoor, A. Plasma membrane compartmentalization of D2 dopamine receptors. J. Biol. Chem. 2013, 288, 12554-12568. [CrossRef]

121. Cho, D.I.; Min, C.; Jung, K.S.; Cheong, S.Y.; Zheng, M.; Cheong, S.J.; Oak, M.H.; Cheong, J.H.; Lee, B.K.; Kim, K.M. The N-terminal region of the dopamine D2 receptor, a rhodopsin-like GPCR, regulates correct integration into the plasma membrane and endocytic routes. Br. J. Pharmacol. 2012, 166, 659-675. [CrossRef]

122. Young, C.; Gean, P.W.; Chiou, L.C.; Shen, Y.Z. Docosahexaenoic acid inhibits synaptic transmission and epileptiform activity in the rat hippocampus. Synapse 2000, 37, 90-94. [CrossRef]

123. Itokazu, N.; Ikegaya, Y.; Nishikawa, M.; Matsuki, N. Bidirectional actions of docosahexaenoic acid on hippocampal neurotransmissions in vivo. Brain Res. 2000, 862, 211-216. [CrossRef]

124. Rapoport, S.I.; Chang, M.C.; Spector, A.A. Delivery and turnover of plasma-derived essential PUFAs in mammalian brain. J. Lipid Res. 2001, 42, 678-685. [CrossRef]

125. Rapoport, S.I.; Rao, J.S.; Igarashi, M. Brain metabolism of nutritionally essential polyunsaturated fatty acids depends on both the diet and the liver. Prostaglandins Leukot. Essent. Fat. Acids 2007, 77, 251-261. [CrossRef]

126. Pan, Y.; Scanlon, M.J.; Owada, Y.; Yamamoto, Y.; Porter, C.J.; Nicolazzo, J.A. Fatty Acid-Binding Protein 5 Facilitates the Blood-Brain Barrier Transport of Docosahexaenoic Acid. Mol. Pharm. 2015, 12, 4375-4385. [CrossRef] [PubMed]

127. Pan, Y.; Short, J.L.; Choy, K.H.; Zeng, A.X.; Marriott, P.J.; Owada, Y.; Scanlon, M.J.; Porter, C.J.; Nicolazzo, J.A. Fatty Acid-Binding Protein 5 at the Blood-Brain Barrier Regulates Endogenous Brain Docosahexaenoic Acid Levels and Cognitive Function. J. Neurosci. 2016, 36, 11755-11767. [CrossRef] [PubMed]

128. Yu, S.; Levi, L.; Casadesus, G.; Kunos, G.; Noy, N. Fatty acid-binding protein 5 (FABP5) regulates cognitive function both by decreasing anandamide levels and by activating the nuclear receptor peroxisome proliferator-activated receptor beta/delta (PPARbeta/delta) in the brain. J. Biol. Chem. 2014, 289, 12748-12758. [CrossRef]

129. Li, B.; Reynolds, J.M.; Stout, R.D.; Bernlohr, D.A.; Suttles, J. Regulation of Th17 differentiation by epidermal fatty acid-binding protein. J. Immunol. Baltim. Md. 1950 2009, 182, 7625-7633. [CrossRef]

130. Reynolds, J.M.; Liu, Q.; Brittingham, K.C.; Liu, Y.; Gruenthal, M.; Gorgun, C.Z.; Hotamisligil, G.S.; Stout, R.D.; Suttles, J. Deficiency of fatty acid-binding proteins in mice confers protection from development of experimental autoimmune encephalomyelitis. $J$. Immunol. Baltim. Md. 1950 2007, 179, 313-321. [CrossRef]

131. Rao, E.; Singh, P.; Li, Y.; Zhang, Y.; Chi, Y.I.; Suttles, J.; Li, B. Targeting epidermal fatty acid binding protein for treatment of experimental autoimmune encephalomyelitis. BMC Immunol. 2015, 16, 28. [CrossRef]

132. Wang, Y.; Shinoda, Y.; Cheng, A.; Kawahata, I.; Fukunaga, K. Epidermal Fatty Acid-Binding Protein 5 (FABP5) Involvement in Alpha-Synuclein-Induced Mitochondrial Injury Under Oxidative Stress. Biomedicines 2021, 9, 110. [CrossRef] [PubMed]

133. Hotamisligil, G.S.; Bernlohr, D.A. Metabolic functions of FABPs-mechanisms and therapeutic implications. Nat. Rev. Endocrinol. 2015, 11, 592-605. [CrossRef] [PubMed]

134. Field, C.S.; Baixauli, F.; Kyle, R.L.; Puleston, D.J.; Cameron, A.M.; Sanin, D.E.; Hippen, K.L.; Loschi, M.; Thangavelu, G.; Corrado, M.; et al. Mitochondrial Integrity Regulated by Lipid Metabolism Is a Cell-Intrinsic Checkpoint for Treg Suppressive Function. Cell Metab. 2020, 31, 422-437.e5. [CrossRef]

135. Pan, Y.; Tian, T.; Park, C.O.; Lofftus, S.Y.; Mei, S.; Liu, X.; Luo, C.; O’Malley, J.T.; Gehad, A.; Teague, J.E.; et al. Survival of tissue-resident memory $\mathrm{T}$ cells requires exogenous lipid uptake and metabolism. Nature 2017, 543, 252-256. [CrossRef]

136. Ma, D.; Zhang, M.; Mori, Y.; Yao, C.; Larsen, C.P.; Yamashima, T.; Zhou, L. Cellular localization of epidermal-type and brain-type fatty acid-binding proteins in adult hippocampus and their response to cerebral ischemia. Hippocampus 2010, 20, 811-819. [CrossRef] [PubMed]

137. Boneva, N.B.; Kaplamadzhiev, D.B.; Sahara, S.; Kikuchi, H.; Pyko, I.V.; Kikuchi, M.; Tonchev, A.B.; Yamashima, T. Expression of fatty acid-binding proteins in adult hippocampal neurogenic niche of postischemic monkeys. Hippocampus 2011, 21, 162-171. [CrossRef] [PubMed]

138. White, R.E.; McTigue, D.M.; Jakeman, L.B. Regional heterogeneity in astrocyte responses following contusive spinal cord injury in mice. J. Comp. Neurol. 2010, 518, 1370-1390. [CrossRef]

139. Bannerman, P.; Hahn, A.; Soulika, A.; Gallo, V.; Pleasure, D. Astrogliosis in EAE spinal cord: Derivation from radial glia, and relationships to oligodendroglia. Glia 2007, 55, 57-64. [CrossRef]

140. Kamizato, K.; Sato, S.; Shil, S.K.; Umaru, B.A.; Kagawa, Y.; Yamamoto, Y.; Ogata, M.; Yasumoto, Y.; Okuyama, Y.; Ishii, N.; et al. The role of fatty acid binding protein 7 in spinal cord astrocytes in a mouse model of experimental autoimmune encephalomyelitis. Neuroscience 2019, 409, 120-129. [CrossRef]

141. Chinta, S.J.; Mallajosyula, J.K.; Rane, A.; Andersen, J.K. Mitochondrial alpha-synuclein accumulation impairs complex I function in dopaminergic neurons and results in increased mitophagy in vivo. Neurosci. Lett. 2010, 486, 235-239. [CrossRef] [PubMed]

142. Cole, N.B.; Dieuliis, D.; Leo, P.; Mitchell, D.C.; Nussbaum, R.L. Mitochondrial translocation of alpha-synuclein is promoted by intracellular acidification. Exp. Cell Res. 2008, 314, 2076-2089. [CrossRef] [PubMed]

143. Lagadic-Gossmann, D.; Huc, L.; Lecureur, V. Alterations of intracellular pH homeostasis in apoptosis: Origins and roles. Cell Death Differ. 2004, 11, 953-961. [CrossRef] [PubMed]

144. Tsai, K.L.; Wang, S.M.; Chen, C.C.; Fong, T.H.; Wu, M.L. Mechanism of oxidative stress-induced intracellular acidosis in rat cerebellar astrocytes and C6 glioma cells. J. Physiol. 1997, 502, 161-174. [CrossRef] [PubMed] 
145. Marini, A.M.; Nowak, T.S., Jr. Metabolic effects of 1-methyl-4-phenylpyridinium (MPP(+)) in primary neuron cultures. J. Neurosci. Res. 2000, 62, 814-820. [CrossRef]

146. Seo, J.H.; Kang, S.W.; Kim, K.; Wi, S.; Lee, J.W.; Cho, S.R. Environmental Enrichment Attenuates Oxidative Stress and Alters Detoxifying Enzymes in an A53T $\alpha$-Synuclein Transgenic Mouse Model of Parkinson's Disease. Antioxidants 2020, 9, 928. [CrossRef]

147. Wi, S.; Lee, J.W.; Kim, M.; Park, C.H.; Cho, S.R. An Enriched Environment Ameliorates Oxidative Stress and Olfactory Dysfunction in Parkinson's Disease with $\alpha$-Synucleinopathy. Cell Transplant. 2018, 27, 831-839. [CrossRef]

148. Zhu, Z.J.; Wu, K.C.; Yung, W.H.; Qian, Z.M.; Ke, Y. Differential interaction between iron and mutant alpha-synuclein causes distinctive Parkinsonian phenotypes in Drosophila. Biochim. Biophys. Acta 2016, 1862, 518-525. [CrossRef] [PubMed]

149. Ostrerova-Golts, N.; Petrucelli, L.; Hardy, J.; Lee, J.M.; Farer, M.; Wolozin, B. The A53T alpha-synuclein mutation increases iron-dependent aggregation and toxicity. J. Neurosci. 2000, 20, 6048-6054. [CrossRef] 